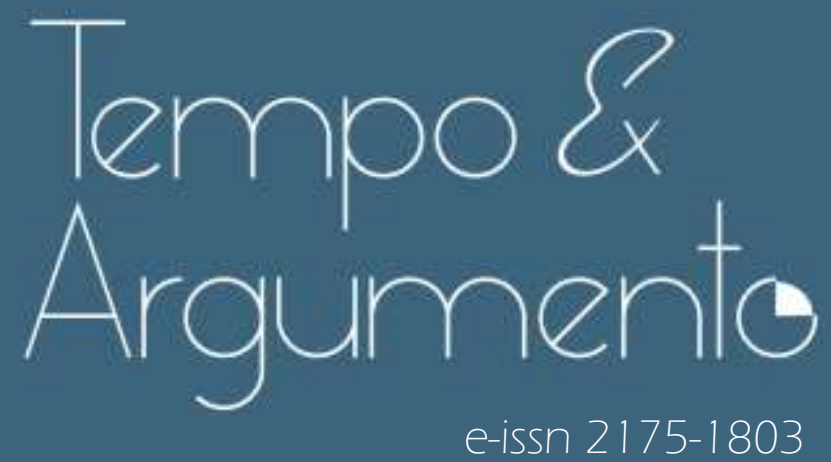

\title{
A autoestima piauiense, os usos políticos e as repercussões na memória
}

- Claudia Cristina da Silva Fontineles

Doutora em História pela Universidade Federal de Pernambuco (UFPE).

Professora Permanente do Programa de Pós-Graduação em História, do Departamento de História, e do Programa de Pós-Graduação em Ciência Política da Universidade

Federal do Piauí (UFPI). Bolsista em Produtividade Científica/UFPI. Membro do Núcleo

Cidade, Tempo e Espaço e do Núcleo de Pesquisa em História e Educação.

Teresina, PI - BRASIL

lattes.cnpq.br/8352484392271532

cfontinelles@gmail.com

(D) orcid.org/0000-0001-5398-0354

Para citar este artigo:

FONTINELES, Claudia Cristina da Silva. A autoestima piauiense, os usos políticos e as repercussões na memória. Tempo e Argumento, Florianópolis, v. 13, n. 33, e0210, maio/ago. 2021.

dol http://dx.doi.org/10.5965/2175180313332021 e0210

Recebido: 09/04/2020

Aprovado: 09/02/2021 


\title{
A autoestima piauiense, os usos políticos e as repercussões na memória $^{1}$
}

\begin{abstract}
Resumo
O presente texto discute em que medida os meios de representação produzidos pelo e sobre o governo de Alberto Silva, em sua primeira gestão como governador do estado do Piauí (1971-1975), contribuíram para difundir a crença sobre este governo ser o principal responsável pela construção da autoestima piauiense, e por conseguinte, pela formação da identidade piauiense. O texto visa a discutir como esses discursos repercutiram na memória e na história da comunidade local a ponto de se irradiarem até entre os adversários políticos do referido administrador. Defendemos que esse projeto de construção de um ideal otimista não estava restrito ao Piauí, e que tampouco ocorreu de forma isolada e inusitada, como fruto da decisão de um só homem, pois estava articulado à configuração histórica vigente no país. Para tanto, recorremos aos conceitos de identidade - a partir das contribuições formuladas por Stuart Hall e por Zygmunt Bauman; memória - a partir dos estudos realizados por Paul Ricœur e por Michel de Certeau -; e de representação, nas discussões de Roger Chartier. A partir da crítica documental e da metodologia da História Oral, analisamos os documentos oficiais, matérias jornalísticas publicadas em veículos midiáticos impressos de circulação nacional e em televisivos locais, que abordaram esse tema, durante e após o término de seu governo, além de relatos do próprio governador, de seus aliados e de seus adversários políticos, visando a entender como essas construções discursivas influenciaram a história e a memória piauiense.
\end{abstract}

Palavras-chave: História; política; identidade; memória.

\section{The self-esteem piauiense, the political uses and the repercussions on memory}

\begin{abstract}
This text discusses how the means of representation produced by and about the government of Alberto Silva, in his first administration as governor of the state of Piauí (1971-1975), contributed to spread the belief about this government being the main responsible for the construction of piauiense self-esteem, and therefore for the formation of piauiense identity. The text aims to discuss how these discourses resonated in the memory and history of the local community to the point of radiating even among the political opponents of the said administrator. We argue that this project of construction of an optimistic ideal was not restricted to Piauí, and that it did not occur in isolation and unusual, as a result of the decision of one man, and that it was articulated to the historical configuration in force in the country. To this end, we use the concepts of identity - from the contributions made by Stuart Hall and Zygmunt Bauman; memory - from the studies carried out by Paul Ricœur and Michel de Certeau - and representation, in the discussions of Roger Chartier. Based on document criticism and on the Oral History methodology, we analyzed the official documents, journalistic articles published in national printed media and in local television, which approached this theme during and after the end of his government, as well as reports from the governor himself, from his allies, and from his political opponents, in order to understand how these discursive constructions influenced the history and the memory of Piauí.
\end{abstract}

Keywords: History; policy; identity; memory.

A realização desta pesquisa contou com o apoio do Programa de Bolsa de Produtividade em Pesquisa Científica da Universidade Federal do Piauí. 


\title{
Introdução
}

\author{
Preciso ser um outro \\ para ser eu mesmo. \\ Existo onde me desconheço \\ aguardando pelo meu passado \\ ansiando a esperança do futuro. \\ No mundo que combato \\ morro \\ no mundo por que luto \\ nasço. \\ (COUTO, Mia, 2006, p. 86)
}

O governo de Alberto Silva contribuiu de maneira decisiva para dar centralidade às discussões sobre a identidade piauiense, ao promover o debate sobre sua importância para a história local, influenciando sobremaneira as discussões acerca da identidade dessa sociedade no período que compreende sua primeira administração à frente do executivo estadual (1971-1975), seja por meio da construção de sistemas de representação que evidenciavam tal tema; seja pelo desejo personalístico de autopromoção política de si junto à sociedade local, naquilo que Paul Ricœur denominou de "memória exercitada", a memória “cultivada, educada, esculpida” (RICOEUR, 2007, p. 77).

O presente texto discute em que medida os meios de representação produzidos pelo e sobre o primeiro governo de Alberto Silva, na década de 1970, contribuíram para difundir a crença sobre este governo ser o principal responsável pela construção da autoestima piauiense, e por conseguinte, pela formação da identidade piauiense. O texto visa a discutir como a eficiência desses discursos repercutiu na memória e na história da comunidade local a ponto de se irradiar até entre os adversários políticos do referido administrador. Defendemos, contudo, que isso, embora tenha gerado repercussões sobre como a sociedade local percebia a si mesma, não era uma ação isolada e original, mas estava em consonância com o projeto político estratégico em vigência no país no período.

Para tanto, abordamos identidade a partir das contribuições formuladas por Stuart Hall e por Zygmunt Bauman, e memória a partir dos estudos realizados por Paul Ricœur e por Michel de Certeau, além de representação, mediante os estudos 
de Roger Chartier. Adotamos como metodologia de estudo, a pesquisa documental a partir do uso de fontes em documentos oficiais, em matérias jornalísticas publicadas em veículos midiáticos impressos de circulação nacional e televisivos locais, - durante e após o término desse seu governo -, além do uso da metodologia da História Oral (ALBERTI, 2010; AMADO; FERREIRA, 2006; BÉDARIDA, 2006; BENJAMIN, 1987; FERREIRA, 2012), a partir dos relatos do governador do estado, de seus aliados e de seus adversários políticos, visando a entender como essas construções discursivas influenciaram a história e a memória da sociedade piauiense acerca dessa temática.

\section{O Piauí em sintonia com o projeto de "Brasil Gigante"}

E se "todas as identidades estão localizadas no espaço e no tempo simbólicos" (HALL, 2015, p. 41) é fundamental analisar que essas construções estão amparadas em valores e significados construídos simbolicamente em cada configuração histórica que as elaborou. Afinal, “as lutas de representação têm tanta importância como as lutas econômicas para compreender os mecanismos pelos quais um grupo impõe, ou tenta impor", seus valores e seu domínio (CHARTIER, 1988, p. 17).

Para entender como o primeiro governo de Alberto Tavares Silva² (1971-1975) se projetou como o principal responsável pela construção da autoestima piauiense, consideramos ser fundamental entender como se construíram as representações culturais nesse período e como eram pensadas as identidades pelos governos da época. É necessário entender que esse governo se deu num contexto de intensa propaganda voltada para a construção de uma percepção otimista sobre os governos autoritários, que deram vazão a um discurso ufanista de pertencimento a um "Brasil Gigante", em uma flagrante contradição ao cenário de supressão de direitos políticos, civis e sociais, que se configurou no solapamento da democracia no país.

\footnotetext{
2 Nascido em Parnaíba, em 1918. Governou o Piauí em duas oportunidades (1971-1975 e 1987-1991; na primeira, através da nomeação dos presidentes militares; na segunda, pelo voto direto da população). Assumiu, entre outros cargos, os mandatos de Senador da República (1979-1987 e 1999-2007), e de deputado federal (1995-1999 e 2007-2009). Faleceu em 2009, ainda no exercício do mandato parlamentar.
} 
Dessa forma, é contraditório, pensar em se constituir uma imagem de sociedade com autoestima elevada em um país com uma população aviltada em seus direitos elementares, uma população amordaçada, ameaçada em suas liberdades e impedida de sequer se expressar e de escolher seus representantes políticos. Todavia, a história traz consigo a ambiguidade como uma de suas principais marcas, sobretudo quando se observa que ela é multifacetada e composta de muitas especificidades. Daí o papel dos meios de representação para entender cada tempo, sobretudo seu significado na construção das identidades sociais.

Para entender como se projetou sobre a memória social piauiense o discurso de que a década de 1970 - mais especificamente nos governos de Alberto Silva teria sido um tempo de euforia e de prosperidade, no qual a autoestima da população teria se consolidado, é necessário compreender como esse discurso estava em conformidade com o projeto de governo instituído em todo o país, no período.

Beatriz Kushnir, ao abordar como isso se deu no campo das ações e das representações, esclarece que "acima de tudo, as normas legais do pós-1964 foram ordenadas dentro da perspectiva da Doutrina de Segurança Nacional, cerceando informações para impor uma imagem de "Brasil Gigante”. Além disso, endossa que "a censura prestou um serviço aos governos da ditadura civil-militar pós-1964, atuando com deseducadora de várias gerações" (KUSHNIR, 2012, p. 81, grifo nosso).

Alçado ao comando político do Piauí de maneira indireta pela alta cúpula dos generais, num contexto de governos de exceção, o mandato de Alberto Silva iniciava-se num cenário de explícito enrijecimento do regime ditatorial instaurado no Brasil a partir do golpe civil-militar de 1964, que se agravaria principalmente após a aprovação do Ato Institucional n. 5³, que, entre outras medidas, implantou a Doutrina de Segurança Nacional (DSN), com a intensiva participação de agências

\footnotetext{
${ }^{3}$ Carlos Fico (2007) defende que a censura não foi uma criação do Regime Militar, uma vez que existia sob a forma de leis de imprensa e seus similares, mas os governos militares a institucionalizaram e recorreram a ela de maneira mais explícita e violenta. A partir da aprovação do Al-5, em dezembro de 1968, o governo, entre outras medidas ditatoriais, recorreu à censura às liberdades de expressão e de reunião, restringiu os poderes do Congresso e do Judiciário, interveio politicamente em estados e municípios e suspendeu os direitos políticos e individuais. (FICO, 2007; GRINBERG, 2009; KUSHNIR, 2012; MARTINS; LUCA, 2008).
} 
oficiais nas decisões do governo, como a Assessoria Especial de Relações Públicas $(\mathrm{AERP})^{4}$, criada em janeiro de 1968, que passou a desenvolver campanhas de comunicação social que difundissem ideias otimistas em relação àquele período histórico e às ações executadas pelo regime vigente, com ênfase ao caráter nacionalista.

A AERP - seguindo o método de análise da Escola de Estado-Maior - adotou a expressão "relações públicas" como um eufemismo para evitar usar o termo "propaganda política”, embora fosse o que ela promovia. Esse órgão responsabilizou-se pela comunicação social e pela proteção da imagem do regime militar junto à sociedade, tendo os seguintes objetivos: "'motivar a vontade coletiva para o esforço nacional de desenvolvimento'; 'mobilizar a juventude’; 'fortalecer o caráter nacional'; 'estimular o amor à pátria'; a 'coesão familiar'; a 'dedicação ao trabalho'; a ‘confiança no governo' e a ‘vontade de participação’” (FICO, 2007, p. 196). Essas campanhas visavam passar um "ar de legitimidade" ao regime, tentando projetar, ainda que artificialmente, seu caráter democrático. Para tanto, a AERP implantou um "projeto pedagógico" autoritário para difundir entre a sociedade o “caráter nacional", cujo cerne seria a cordialidade, a hospitalidade e o culto às riquezas naturais do território nacional (FICO, 2007, p. 197).

Sob a liderança de Otávio Costa e Toledo Camargo, esse órgão elaborou um projeto de propagandas que se propunha a "estimular" e "educar" a sociedade (a exemplo dos slogans "Ninguém segura o Brasil" e "Este é um país que vai pra frente"), junto ao projeto que visava a "demonstrar força" (a exemplo do slogan "Brasil: ame-o ou deixe-05"), como realça Carlos Fico (2007, p. 198).

Nem o aparente crescimento econômico vivido no país - restrito apenas a alguns segmentos da sociedade brasileira - foi capaz de conter as reações críticas frente aos rumos político-sociais que o Brasil seguia, evidenciadas pelos baixos

\footnotetext{
${ }^{4}$ Implantada em 15 de janeiro de 1968, após a divulgação de uma pesquisa do Instituto Brasileiro de Opinião Pública e Estatística (IBOPE) revelar a baixa popularidade do Regime Militar entre os brasileiros, a AERP foi criada para coordenar as relações públicas do Regime de maneira mais sistemática, tendo atuado até março de 1974, num período que coincidiu com a maior parte do mandato de Alberto Silva no governo do Piauí (março de 1971 a março de 1974). (ABREU; PAULA, 2007; FICO, 2007).

5 Este slogan foi proposto pela Operação Bandeirante (OBAN) e não pela AERP, indicando que havia propostas diferentes a respeito de como conduzir a "comunicação social" no regime militar (FICO, 2007).
} 
índices de popularidade do governo ou pelas diferentes formas de resistência criadas por segmentos sociais. Era necessário um projeto mais arrojado no campo da comunicação social, que convencesse a sociedade de adesão ao discurso governamental, o que redundou na criação de meios de representação que visavam à propagação de uma visão otimista do Brasil, à medida que freavam qualquer reação de crítica ao governo. Isso ocorreu através de campanhas publicitárias e de propagandas, difundidas tanto por empresas públicas quanto por empresas privadas, com o apoio estatal - por meio de propagandas oficiais ou por propagandas dissimuladas de matérias jornalistas -, geralmente em troca do apoio financeiro do governo à modernização técnica das empresas de comunicação.

É muito revelador o fato de ter sido durante o Regime Militar que a imprensa escrita, o rádio e a televisão, passaram a depender fundamentalmente da publicidade estatal para funcionar, posto serem os entes públicos os principais anunciantes (ABREU, 2008). No Piauí, foi a partir da década de 1970 que os jornais de maior circulação tiveram seus parques gráficos e seus projetos editoriais de suas impressões modernizados.

Alzira Abreu relaciona a expansão dessas redes de comunicação à estratégia política de segurança nacional, uma vez que implantava um sistema de informação que buscava "integrar" o país e facilitava a irradiação de "todas as atividades fundamentais em termos políticos" (ABREU, 2008, p. 472).

Essa aproximação entre imprensa e os governos autoritários também se fez notar na manifestação da autocensura promovida nos meios de comunicação, seja por medo das sanções, por omissão ou por apoio deliberado, naquilo que ficou conhecido como "pacto de responsabilidade", uma vez que, antes mesmo de o governo promulgar o Decreto n. 1.077, em março de 1970, que instituía a censura prévia, as empresas e os jornalistas já praticavam a autocensura em suas edições (KUSHNIR, 2012; SODRÉ, 1983).

Nesse sentido, os meios de comunicação passaram a ser fundamentais na construção de uma imagem próspera de país, uma vez que parte dos jornalistas e das empresas de comunicação, dentre tantos setores da sociedade civil que apoiaram os governos militares, passaram a contribuir com a autocensura, sendo mais um "alicerce" dessa ditadura como fruto de um acordo civil-militar. Esses 
jornalistas, como "cães de guarda", "à soleira, montaram a guarda e fizeram autocensura no governo Médici, e mesmo antes dele, colaborando para construir e difundir uma imagem irreal, inverídica do país (KUSHNIR, 2012, p. 52).

Todos esses elementos de censura, publicidade e propaganda, centrados na difusão do otimismo como forma de criar uma certa unidade interna e de conquistar o apoio popular - promovidos pelos governos militares e pelas forças civis que os apoiaram e thes deram sustentação -, ganharam centralidade no projeto governamental de Alberto Silva e contribuíram para a projeção de seus feitos entre a sociedade piauiense, mesmo depois da década de 1970.

Em sintonia com o projeto político nacional, seu governo passou a investir em campanhas de promoção daquilo que fora denominado de "autoestima do povo piauiense", sobretudo após a criação, pelo governo estadual, da Assessoria de Acompanhamento e Comunicação (AGE), assumida por Armando Madeira Basto ${ }^{6}$, considerado como um super secretário, o "mago das comunicações”7 do governo Alberto Silva, que intensificou o investimento em publicidade e em financiamentos públicos nas principais empresas de comunicação do estado, contribuindo para construir uma rede de apoio que o auxiliou na divulgação do discurso de um "Piauí Próspero", no esteio do "Brasil Gigante”.

Embora este texto não tenha o propósito de analisar especificamente os meios de comunicação, mencionamos essa aproximação entre o governo e a mídia para realçar como esses meios contribuíram para projetar e fixar a imagem do

\footnotetext{
Considerado assim pelo forte prestígio que gozava no governo estadual. Conterrâneo e contemporâneo de estudos do governador no Ginásio Parnaibano, o advogado e jornalista Madeira Basto, antes de assumir a AGE, ocupou vários cargos de prestígio em nível federal, a exemplo do cargo de diretor geral da Agência Nacional, no governo do presidente Costa e Silva, e o de secretário do Serviço de Imprensa, chefe do Serviço de Rádio e Difusão e secretário de Redação do programa A Voz do Brasil. (TAVARES, 2018). Esses cargos ocupados por Madeira Basto evidenciam o nível de aproximação técnica e ideológica existente entre o governo albertista e o comando político do Brasil, sobretudo no que concerne à construção da imagem pública do governo junto à sociedade. Denominação usada pelo jornalista Zózimo Tavares (2018).

8 É importante lembrar que, além dessa aproximação aos órgãos de comunicação social, este governo também criou um arrojado programa de investimentos nos setores da infraestrutura, da educação e da cultura do estado, entre os quais destacam-se projetos que realçavam a ideia de Piauí próspero e de identidade piauiense (a exemplo do incentivo a publicações de livros sobre o estado, construção de monumentos arquitetônicos suntuosos ou que retratassem eventos da história mafrense, a criação da Secretaria de Cultura e da Empresa Piauiense de Turismo PIEMTUR, que visava dar destaque às belezas naturais e aos pontos turísticos locais, entre tantas outras ações voltadas para a imagem do piauiense junto aos outros e a si mesmo), o que intensificou a adesão social ao discurso de euforia que se projetou sobre esse governo.
} 
ex-governador como um agente central na construção do otimismo e como o responsável pela construção da autoestima do povo piauiense, tendo isso funcionado como insígnia que o projetou na memória e na história do Piauí.

Defendemos, contudo, que esse projeto de construção de um ideal otimista não estava restrito ao Piauí, e que tampouco ocorreu de forma isolada e inusitada, como fruto da decisão de um só homem, e sim que estava articulado à configuração histórica vigente no país, tendo assumido a centralidade no programa de governo brasileiro. Essa relação quase sempre é omitida nos discursos produzidos sobre o governo de Alberto Silva e essa omissão afetou a maneira como a sociedade trata esse tema.

\section{De "estrangeiro" a "construtor" da autoestima piauiense}

Na perspectiva dos aliados de Alberto Silva, ao chegar ao governo do estado do Piauí, em 1971, por meio da nomeação do presidente Emílio Garrastazu Médici, ele estava dissociado dos grupos majoritários e tradicionais da política piauiense (que tinham em Petrônio Portella Nunes ${ }^{9}$ seu principal líder), assumindo-se como o novo, em oposição ao antigo, no cenário local. Daí a associação de seu nome como "estrangeiro", como "forasteiro" na política piauiense ${ }^{10}$. Tal visão embasavase no fato de que mesmo sendo piauiense, filho do município de Parnaíba, tinha sido indicado governador pelas forças políticas do Ceará11. Sobre sua nomeação declarou:

\footnotetext{
9 Petrônio Portella Nunes, nascido em Valença, em 1925, entre outros cargos, presidiu o Senado e o Congresso Nacional em duas ocasiões (1971-1973 e 1977-1979). Líder da Arena e do governo (19731977). Presidente nacional da ARENA entre os anos de 1973-1975). Condutor da "Missão Portella", no governo de Ernesto Geisel, no processo de distensão política. Ministro da Justiça no governo de João Baptista Figueiredo (1979-1980). Faleceu em janeiro de 1980 em exercício do cargo de senador.

10 É importante ressaltar que, embora Petrônio Portella gozasse de muito prestígio junto aos governos militares na década de 1970, durante o governo de Emílio Médici, isso não foi suficiente para permitir que indicasse o nome do governador do Piauí. A indicação de Alberto Silva advinha de forças externas aos poderes políticos tradicionais do Piauí. Na sucessão estadual de 1974, Portella teve a prerrogativa de indicar o nome do governador do Piauí.

${ }^{11}$ Foi eleito ainda deputado estadual na eleição de 1950, cargo do qual se afastou apenas para assumir outras funções de direção de órgãos públicos ligados ao transporte coletivo ou ao abastecimento elétrico, áreas associadas à sua atuação como engenheiro. Durante a década de 1960, assumiu cargos técnicos no estado do Ceará, nas gestões de Virgílio Távora - com quem tinha laços familiares - e de Plácido Castelo. Foi nessa relação que construiu os laços com as forças políticas que o indicaram ao governo do Piauí.
} 
Bem, como nós estamos falando para a história, e muitas dessas pessoas já não estão mais aqui nesse mundo, e que Deus os guarde, mas o comandante principal era o poderoso ministro Petrônio Portella, evidentemente ele era o líder político do Piauí e eu era o estrangeiro que estaria chegando aqui, possivelmente a classe política forçou, não digo que fosse ele pessoalmente, mas a classe que o seguia, me olhava como um estrangeiro, que ia chegar aqui pra fazer o quê? (SILVA, 2006, grifo nosso. Informação verbal) ${ }^{12}$

A cautela demonstrada por Alberto Silva quando esclarece que seu depoimento significa estar "falando para a história" indica o grau de consciência que ele tem acerca dos registros deixados no tempo e do caráter valioso que isso tem na construção da memória e da história de um povo. Isso remete ao que Paul Ricœur denomina de “apoios externos” para a memória, uma vez que, segundo ele, "quando não fazemos mais parte do grupo na memória do qual tal lembrança se conservava, nossa própria memória se esvai por falta de apoios externos" (RICOEUR, 2007, p. 131). O ex-governador, assim, expressa o desejo por conseguir, com suas declarações, apoios externos para a conservação de sua imagem na memória do Piauí.

Referindo-se ainda à resistência a seu nome por seus adversários, chegou a afirmar que eles pareciam "que tinham um certo receio que eu mudasse as coisas no Piauí e aconteceu que eu mudei mesmo" (SILVA, 2006). A perspectiva da mudança, e junto dela, a defesa do progresso são uma constante nesses depoimentos. Em mais essa oportunidade, faz questão de afirmar que seu governo se traduziu como símbolo da inovação, fazendo da recitação de seus atos uma inscrição no tempo e na memória, recorrendo ao que Paul Ricœur denominou de "ato de recitar" como suporte de qualquer recordação. Se a recordação carece de recitação para ser despertada, encontrava em Alberto Silva um veículo inconteste para permanecer alerta e atuante, pois ele não esperava que outros destacassem seus feitos; ele próprio inaugurou tal atitude e a propagava por onde transitasse.

Novamente, a ideia de ser o guardião das mudanças e responsável pelas principais transformações que marcaram o Piauí é enfatizada em sua narrativa

\footnotetext{
${ }^{12}$ Os principais nomes cogitados para serem os indicados por Portella ao governo do Piauí, para o mandato que se iniciaria em 1971 eram os de Bernardino Soares Viana - seu suplente no Senado Federal, e Stanley Fortes Batista, que fora tratado como futuro governador do Piauí pela matéria da revista Veja: "[...] o Coronel Stanley Fortes Batista, marcou de tal forma sua passagem na administração, que agora está-se preparando para assumir o governo do Piauí" (OS MILITARES..., 1970, p. 2)
} 
sobre seu primeiro governo. Até o fato de destacar que seu nome foi associado à figura de um forasteiro é aproveitado para construir sua imagem como o contrário disso: ao invés de forasteiro que nada entendia do Piauí e que pouco contribuiria para melhorar a vida de sua gente, Alberto Silva construiu uma imagem de construtor e de condutor da laborosa tarefa de afirmar a autoimagem que o piauiense tinha de si e do seu estado, bem como teria contribuído para a população ter maior afinidade e identidade com sua terra, graças às transformações que promovera em solo piauiense.

Ao inverter para propagador da identidade piauiense a imagem de "estrangeiro" que seus detratores criaram de si, Silva passa a utilizá-la como escudo contra as críticas, fazendo o movimento inverso: de forasteiro tornava-se o mais ferrenho defensor da identidade piauiense. Nessa trajetória, atrela identidade ao lugar de nascimento, bem como à ideia de sentimento de pertencimento, propagando que mesmo tendo construído sua vida acadêmica e profissional fora do Piauí, a ele pertencia por nele ter nascido e com ele se identificar.

Ao combater o discurso excludente utilizado contra si, passa a encontrar na defesa de uma identidade piauiense o suporte para resistir às críticas e às oposições, tratando identidade como algo que se pudesse capturar em pleno voo, como se fosse amparada em âncoras que a prendessem a um lugar específico, na busca da "identidade mestra" assegurada pelo "teto político" do território de nascimento, tão defendidos pelo ideal iluminista (HALL, 2015). Ignorando que as identidades transitam e não se deixam apreender em uma única definição, nem experiência, passou a se referir à identidade piauiense como algo fixo e coeso, cujas fronteiras seriam bem definidas, assim como fizeram seus oponentes ao chamálo de "estrangeiro".

Ao pronunciar-se como piauiense, relaciona isso às fronteiras territoriais, com o território geográfico, e com sua cultura. Ao fazer isso, alegava empreender uma luta contra a fragmentação e a dissolução, fazendo da defesa da identidade piauiense uma batalha contra aquilo que seria uma exclusão, ao mesmo tempo em que ao defendê-la, passou também a promover a segregação do que seriam os "outros" contrários aos piauienses, semelhante ao que faziam seus combatentes em relação a ele. 
A defesa da identidade piauiense estava carregada de ambivalência, pois ao ir ao seu encontro, propunha-se também a distinção em relação a grupos diferentes, uma vez, como indica Zygmunt Bauman, "as batalhas de identidade não podem realizar a sua tarefa de identificação sem dividir tanto quanto, ou mais do que, unir" (BAUMAN, 2005, p. 85). Se Alberto Silva foi tratado como "um estranho no ninho que aportou no Palácio de Karnak, por injunções dos coronéis”, como destacou o jornalista Zózimo Tavares (2000, p. 89), ele próprio passou a propagar em seu governo a defesa de uma identidade piauiense fortalecida, passando a estabelecer divisões, classificações entre os de dentro e os de fora, entre pertencimento e exclusão ao território piauiense. Ao fazer isso, estabeleceu fronteiras, como se a identidade não fosse uma contínua bricolagem, formada por existências fatiadas, que ora se atraem, ora se repelem num continum de semelhanças e diferenças que aprendem a conviver e muitas vezes a se misturar umas com as outras.

Baseando-se nessa postura, a administração albertista passou a valorizar bastante a ideia de ser construtora da autoestima piauiense e sua condutora. Seus interlocutores passaram a dar destaque a isso tanto quanto ele mesmo, tornandose caixas de ressonância para tal discurso. Ao perscrutarmos as fontes, encontramos discussões que defendem esse caráter, seja entre seus aliados, seja entre seus oponentes. Isso é percebido nos pronunciamentos governamentais, ao comentar sobre a mudança de visão dos turistas sobre o Piauí: "Anedota - Vamos ao Piauí, antes que acabe - foi transformada pela euforia dos turistas satisfeitos, na advertência de que é preciso partir de Teresina, antes de resolver ficar para sempre" (PIAUÍ, 1975, p. 10).

O pronunciamento de Alberto Silva, na última mensagem enviada por seu governo à Assembleia Legislativa, parecia pretender responder a todas as críticas recebidas pelo estado, sendo as escritas pelo escritor Nelson Rodrigues as que mais repercutiram no cenário piauiense e nacional. Da coluna que escrevia no jornal carioca O Globo, com a acidez e ironia que the eram peculiares, Rodrigues elegeu o Piauí como um dos alvos preferidos para sua metralhadora giratória de ofensas: "Nesse país, o Piauí é o maior silêncio impresso que se conhece" (RODRIGUES, 2008, 
l. 3945, grifo nosso) ou "É preciso que, de repente, baixe, em todo o Estado, a consciência do próprio inferno" (RODRIGUES, 2008, L. 3210) ${ }^{13}$.

Discursos como os proferidos pelo governador Alberto Silva permitem notar o desejo em contrariar a visão negativa construída em relação ao Piauí. Contudo, terminavam por reforçar tal ideia, à medida que enfatizavam que o desenvolvimento comemorado era referente à capital piauiense. Por que não mencionar todo o estado? A ânsia por evidenciar o clima de prosperidade em Teresina é constante na fala governamental, que aproveita toda oportunidade para pronunciar sua contribuição rumo à inclusão do Piauí no cenário "civilizado" a que tanto se almejava e se difundia na década de 1970.

O discurso, talvez, tenha sido também uma tentativa de reação a outro texto ferino de Nelson Rodrigues, que, ao se referir a Teresina, disse desconhecer o nome da capital piauiense e, após ironizar até a escrita do nome da cidade, asseverou: "O pior vocês não sabem: recebo convites para ir a Teresina. Portanto, vejo que a imprensa, o povo, as autoridades piauienses pensam que as feridas de um povo são turísticas" (RODRIGUES, 2008, l. 3205, grifo nosso).

Por sua vez, o governo albertista aproveita toda oportunidade para fixar a imagem de um Piauí muito diferente, com um discurso de prosperidade, como ao tratar da reforma feita no Palácio do Governo do estado, o Karnak:

Restaurei o Palácio, por dentro e por fora. A majestade de suas linhas e seu harmonioso corpo arquitetônico erguem-se, na moldura do parque arborizado, como documento vivo da vocação civilizatória do povo, e o refinado bom gosto de seus interiores testemunha os padrões de prosperidade de que somos capazes. (PIAUÍ, 1975, p. 10, grifo nosso)

O gestor logo percebeu que, como uma "comunidade imaginada" que é, a sociedade piauiense e sua identidade careciam de símbolos e de representações; precisava ser contada, por meio de "memórias que conectam seu presente com seu passado e imagens que dela são construídas". Alberto Silva cuidou logo de providenciar esses símbolos sobre o "ser piauiense", procurando criar conexão

\footnotetext{
13 Essas são apenas algumas das várias matérias pejorativas sobre o Piauí, escritas e publicadas originalmente pelo autor no jornal O Globo, no ano de 1969. Parte delas compõe a coletânea de textos do autor, publicada nos anos 2000. Aqui, citamos as referências da consulta na versão em e-book, com as respectivas localizações na plataforma editorial. (RODRIGUES, 2008).
} 
entre as "vidas cotidianas com um destino nacional que preexiste a nós e continua existindo após nossa morte" (HALL, 2015, p. 31).

Seus aliados assumiam a mesma postura. Tomaz Teixeira, por exemplo, é um dos porta-vozes dessa interpretação. Referindo-se ao primeiro governo de Alberto Silva, escreve que:

[...] naquela época, o Piauí era manchete nas revistas, jornais, rádios e televisão Brasil afora, devido a uma administração que sem dúvida alguma foi o grande marco para a arrancada desenvolvimentista, pois além do trabalho que se realizava na área da construção civil, um outro se destacava que era o processo de mudança de mentalidade de um povo introvertido em virtude do descrédito que the transmitiam alguns dos governantes que antecederam Alberto Silva. (TEIXEIRA, 1981, p. 234, grifo nosso).

Na tentativa de capturar e de propagar uma imagem positiva de Alberto Silva, seus assessores o associaram à construção de uma imagem positiva do povo piauiense. Passaram, dessa forma, a trabalhar a memória como a "ausência da coisa lembrada e sua presença na forma de representação", como sugeriu Paul Ricœur (2007, p. 72). A identidade passou a ser tratada e a funcionar como um desses elementos de representação de seu governo, aliás, como seu principal mecanismo de inscrição na memória local. Nessa procura, uma dimensão não poderia ser esquecida: a aprovação externa, expressada pelos registros emitidos pela imprensa nacional e vastamente utilizados para confirmar seu intento de construtor eficiente. Por essa ótica, era necessário que o “Brasil afora” aprovasse a imagem do Piauí para que o piauiense também se aprovasse e mudasse de postura perante sua própria imagem. Mais uma vez o apoio externo é clamado como suporte de sustentação para as propostas defendidas naquele período. Discursos semelhantes a esse passaram a se pautar na concepção de identidade considerada como um destino compartilhado pelos piauienses.

Por esse viés, a identidade piauiense passou a ser estereotipada como algo a ser descoberto e não como um elemento construído e ressignificado por seus construtores. Assim, tornaram-se frequentes discursos que atribuíam a Alberto Silva a inserção do Piauí no mapa nacional, referindo-se ao fato de que em seu governo - mais especificamente o primeiro - foram criadas condições de valorização e de autovalorização dos habitantes desse estado. 
Ao propagar a imagem de Alberto Silva como um construtor do estado do Piauí e também da autoestima de sua gente, Tomaz Teixeira termina também por diluir e reduzir a atuação dos governos que o precederam em relação a essa dimensão. Fazendo isso, mais do que dissipar a imagem dos governos anteriores, esse assessor político visava a construir um mito fundador, defendendo que "o Piauí estava acordado, firme e de pé, e o povo feliz sem mais ter vergonha de dizer que era piauiense" (TEIXEIRA, 1981, p. 24), tratando a história como um quebracabeça cujas peças em si já vinham pré-definidas, restando ser montadas para constituir a figura na íntegra, isto é, a identidade piauiense passou a ser vista como uma imagem a ser composta por elementos pré-definidos, bastando reuni-los para encontrá-la, segundo essa formulação. O governador teria sido o sujeito capaz de promover tal constituição da figura delineada e por isso merecia todo aplauso.

Isso muito se assemelha ao que Stuart Hall enuncia como um dos elementos fundantes na construção das identidades nacionais - aqui entendida como identidade piauiense. Segundo esse autor, citando Gelnner, essa identidade é vista como primordial, com ênfase nas origens, por meio de um despertar da "sonolência" para "reassumir sua inquebrantável existência" (HALL, 2015, p. 32). Até a analogia da identidade como o ato de despertar de um sono profundo assemelhase ao que fora proposto em cenário piauiense.

Contudo, essa visão positiva em relação às decisões albertistas sobre a autoestima piauiense, não foi formulada apenas por seus correligionários políticos. Vários segmentos da sociedade puseram relevo a essa questão, atravessando o tempo e reafirmando-a na memória social piauiense, como ilustra a narrativa de Zózimo Tavares, que ao tratar dos cem fatos mais marcantes do século XX no cenário piauiense, em livro publicado no ano 2000, destacou o trabalho desenvolvido por este governante ao estimular a autoestima dos piauienses, tirando "o Piauí do anedotário nacional" e fazendo-o conquistar respeito e respaldo fora e dentro de suas linhas limítrofes (TAVARES, 2000, p. 89). Essa visão concorda que coube ao governo albertista promover condições para que o estado conquistasse respeito perante o contexto nacional.

Narrativas como essa ilustram que, mesmo com o tempo decorrido, o exgovernador era tratado como um importante agente na consolidação da identidade 
piauiense. Identidade essa vista sob a perspectiva sólida, como se a identidade fosse una e fixa, e não repleta de existências múltiplas e variadas, que comporta diferentes manifestações e interpretações, entre as quais permite visões tanto otimistas quanto pessimistas dos caminhos percorridos e suas tensões. Independentemente de como se entende identidade, as formulações interpretativas encontradas durante a pesquisa possibilitaram notar como o Piauí figurava na década de 1970 como um estado desrespeitado e inferiorizado nas relações de força dentro do território federado, carecendo de suportes para elevarse contra essas proposições.

As matérias jornalísticas e os relatos dos admiradores da gestão albertista informam que isso teria sido alcançado somente a partir das intervenções governamentais promovidas nesse governo, como é o caso do jornalista e escritor contemporâneo de grande respaldo social no cenário local, Zózimo Tavares. Seus textos têm a força de uma chancela às ações promovidas no primeiro governo albertista, contribuindo para fortalecer sua presença na memória da população piauiense, principalmente por corroborar o que muitas outras fontes da época informaram a respeito das conquistas ocorridas no quesito autoestima, nesse período.

\section{A autoestima de um povo: fruto de um decreto governamental?}

Formulações semelhantes às de Tavares contribuem para fortalecer a defesa feita pelo próprio ex-governador, que ao elaborar seus discursos, enfatizou a luta por uma identidade piauiense forte e confiante. Essa proposição atravessou o tempo e marcou seus pronunciamentos. Esse tema é recorrente na quase totalidade de seus discursos oficiais do período. Em mensagem governamental encaminhada à Assembleia Legislativa do Estado do Piauí, em 1o de março de 1972, o então líder do executivo estadual destacava ações nesse sentido, informando que havia se empenhado "em projetar fora de nossas fronteiras imagem nova do Piauí novo, inclusive no plenário da SUDENE” (PIAUí, 1972, p. 3).

Segundo esse discurso, associada à ideia de um estado novo que se erigia, estava a projeção de uma coletividade que deveria ser encarada com otimismo, como prossegue na mesma Mensagem, ressaltando que "era indispensável incutir 
na comunidade piauiense o sentido do otimismo e das grandes certezas, pois sem aspirações coletivas não há desenvolvimento" (PIAUÍ, 1972, p. 2, grifo nosso). A intervenção do poder estatal na construção dessa nova postura sobrepôs-se a qualquer espontaneidade, principalmente porque essa visão otimista era encarada como fruto de um ato deliberado promovido pelo governo e não de uma ação voluntária derivada da população por um autorreconhecimento de suas manifestações histórico-culturais. O mito fundador ou, na denominação de Stuart Hall, "fundacional", novamente se sobrepunha e engolia as expressões geradas coletivamente ${ }^{14}$, com o propósito de "inculcar certos valores e normas de comportamentos através da repetição" como continuidade de um passado, embora dentro de práticas ritualísticas ou simbólicas produzidas na "tradição inventada" (HALL, 2015; HOBSBAWM; RANGER, 1997).

Em mais essa declaração ficam evidentes as conexões do governo de Alberto Silva com os valores semeados pelo regime autoritário vigente no país, na década de 1970, em que se pregava que a modernização e o desenvolvimento promovidos por intermédio da SUDENE, transformariam o "animus do nordestino de nossos dias, cheio de otimismo, fé e esperança, em contraste com um passado recente de pessimismo, angústia e revolta" (BRASIL...,1970 apud CARVALHO, 1987, p. 149). Situado nesse mesmo projeto político de defesa da integração nacional, Alberto Silva difundia a importância da intervenção estatal na construção do otimismo de uma sociedade. As aspirações coletivas, assim, eram vistas como fruto do otimismo semeado pelo governo naquilo por ele denominado de grandes certezas, por meio das quais pautariam seus atos e suas condutas. Era um otimismo que andava de braços dados com a ideia de desenvolvimento. Daí a grande ênfase de seu governo em campanhas de publicidade e propaganda que difundissem esse espírito.

A força desse discurso cravou suas marcas no cenário piauiense, transitando pelo tempo, fincando raízes nos pronunciamentos posteriores. Em 2006, o então senador Alberto Silva, já eleito deputado federal para o pleito que se iniciaria no ano seguinte, comentou sobre as condições em que encontrara o Piauí ao assumir

\footnotetext{
${ }^{14}$ Sandra Jatahy Pesavento (2007) esclarece que as formações sociais, principalmente as cidades, criam seus mitos fundadores, denominados por ela de "pais ancestrais" e "heróis fundadores", por meio dos quais projetam suas marcas de historicidade e ativam seu mundo através dos processos mentais.
} 
o governo do Estado em 1971 e, ao analisar sua atuação na construção da autoestima piauiense, assim se posicionou a respeito:

Bem, eu cheguei ao Piauí, eu creio que assim o destino dos homens é traçado, com fé, o destino do homem é traçado por Deus, Ele seguramente queria que eu chegasse ao Piauí, justamente na hora que o Piauí era tido e era criticado no país. Eu me lembro bem que uma revista, eu estava no Ceará, fiquei revoltado com uma revista de circulação nacional, houve um desentendimento entre a direção da revista ${ }^{15}$ e o governo de então, e aí eles fizeram uma matéria de duas a três páginas de um verdadeiro deboche ao Piauí, e diziam assim, "Visitem o Piauí antes que ele acabe". Depois diziam assim, tinha uma fotografia de um coqueiro, lembro bem disso, uma cadeira de barbeiro em baixo escrito "Barbearia" e uma legenda em baixo dizia, "Barbearia no Piauí é debaixo das árvores por causa do calor". Na capital, os cearenses diziam que a bandeira do Piauí era de couro de bode, e por aí ia. Então eu cheguei aqui, encontrei um povo deprimido, sem nenhuma autoestima. [...] enfim, é, eu tomei a iniciativa de criar autoestima em primeiro lugar, fazer com que a população sentisse que afinal de contas, por que o Piauí tinha que ser assim? Eu disse: "Não, meu amigo, aqui tem bons profissionais, todos hábeis em ajudar, digamos, nesta tarefa de levantar a moral piauiense" (SILVA, 2006, grifo nosso).

O caráter homérico descrito nesse relato fortalece a ideia da criação da autoestima no piauiense por uma decisão governamental centrada na figura de um indivíduo - o governador - que decidira tomar a iniciativa de criá-la e difundi-la junto à população, em clara alusão ao "mito fundacional” (HALL, 2015). Esse desejo funcionaria como uma sentença vinculante em última instância, que, sem apelação, e por meio da qual o convencimento sobre o pertencimento ao Piauí se manifestaria, ao se opor à imagem construída pelo elemento externo representado pela imprensa nacional -, que insultava e desdenhava da imagem do estado, afetando a autoimagem de seus habitantes. Novamente, era necessária a existência de um espectro de inimigo para que se construíssem as fronteiras entre "nós" e os "outros", procurando sedimentar uma identidade piauiense contra o tratamento considerado desonroso recebido até então. Os jornais e revistas com sede em outros estados, e os habitantes desses locais, seriam os inimigos contra

\footnotetext{
${ }^{15}$ A revista mencionada é a Realidade, da Editora Abril, em sua edição publicada em abril de 1967 , intitulada "O Piauí existe", assinada por Carlos Azevedo. Várias outras críticas ao estado foram publicadas na mídia nacional, entre elas, os artigos de Nelson Rodrigues repercutiram com muita intensidade nos periódicos impressos locais (RODRIGUES, 2008).
} 
os quais se deveria lutar através da construção e da propagação da autoestima do piauiense.

Por isso, o insulto ao estado deveria ganhar destaque em detrimento da referência a qualquer outra virtude piauiense para que a população visse que era necessária a reação contrária a essas provocações e, ao mesmo tempo, os governos que se insurgissem contra tais visões fossem aplaudidos e respeitados. Sob essa visão, era mister a existência de um antagonista para que o piauiense se tornasse o protagonista de sua história. Esse protagonismo adviria do combate à visão instituída pelo outro e não como elemento endógeno e espontâneo, construído nas relações socioculturais internas. Daí a força dos exemplos elencados para estimular o piauiense a crer no projeto proposto pelo governo, que deveria ser tratado como seu criador e condutor.

Segundo o discurso, de "povo deprimido", sem "nenhuma autoestima”, o piauiense transformar-se-ia em povo altivo, com "moral" elevada, não por si mesmo, mas por uma "iniciativa" de seu governante. A autoestima não é vista por este discurso como algo que é construído em conjunto, mas como fruto de uma ação governamental, quase o resultado de um decreto. Isso é confirmado em diferentes construções discursivas, ao tratar a população piauiense como um grupo passivo, que necessitava da intervenção e da ação de um governante para apagar o "complexo de inferioridade" ao qual estava submetido, como indica o texto a seguir, ao se referir à população local:

Gente essa que aprendeu a acreditar no Piauí e na capacidade de sair do subdesenvolvimento, depois do primeiro grande Governo Alberto Silva que teve como objetivo básico, tirar-nos do complexo de inferioridade, nos dando orgulho e coragem para reagir ao pessimismo que há muito nos envergonhava, ao ponto de se negar Brasil afora, que éramos piauienses. Quantas vezes isso não aconteceu! A injeção de otimismo do seu primeiro Governo mudou a mentalidade dos piauienses que saíram do complexo de inferioridade para o campo da luta pelo nosso direito de crescer (TEIXEIRA, 1990, p. 9).

Novamente é possível identificar as ações do governo albertista associadas ao combate ao pessimismo e à criação de uma maneira otimista de enxergar o estado e sua gente, como sua principal inscrição na história, identificando-o como o inaugurador dessa prática, ao ponto de declarar que a partir dessa interferência 
o piauiense deixou de se envergonhar e de negar sua origem. Seu governo era tratado quase como um bálsamo corretivo dos problemas vividos, injetando otimismo. Ao que parece, essa estratégia repercutiu favorável a esse administrador, pois a ênfase atribuída às ações governamentais realizadas na primeira administração de Alberto Silva, no sentido de elevar a autoestima da população piauiense, é recorrente nos textos pesquisados que tratam desse período. Seus admiradores e aliados analisam essas realizações com lente de aumento ao ponto de um de seus correligionários, Tomaz Teixeira, ao denunciar as demissões ocorridas na esfera estadual no início da década de 1980, referir-se ao político parnaibano como o "homem que descobriu o Piauí para o Brasil", destacando que ele continuava sendo "o melhor governador do Piauí de todos os tempos" (TEIXEIRA, 1990, p. 31).

Essas formulações eufóricas estavam em sintonia com o projeto dos governos autoritários em nível nacional, e revelam pontos de convergência com as propostas difundidas no cenário brasileiro nos anos de 1970. É importante notar como a declaração hiperbólica de um assessor de Alberto Silva assemelha-se ao raciocínio explicitado pelo pronunciamento do então superintendente da SUDENE que, durante a inauguração do edifício sede desse órgão, tratou o presidente Médici como o outorgador do otimismo nordestino, tratando as realizações do período como uma concessão governamental, em uma exacerbada demonstração dos valores ufanistas em vigor no país. Dirigindo-se ao presidente, ele assim se referiu:

[...] Senhor Presidente, o que Vossa Excelência outorgou a todos os nordestinos foi a realidade de uma região que, sem deixar de ser o velho Nordeste do Brasil, será cada vez mais a imagem viva do novo Brasil do Nordeste. Ninguém perdeu por esperar. E o resultado aí está: este mesmo Nordeste crescendo a 13\% (BRASIL. SUDENE..., 1974 apud CARVALHO, 1987, p. 197, grifo nosso).

No referido pronunciamento, o crescimento do nordeste e do país era atribuído ao seu gestor através de um ato de outorga; em âmbito estadual ocorria algo semelhante, em flagrante consonância entre essas interpretações eufóricas, que intentavam difundir uma percepção otimista do projeto político em vigor, evidenciando que as diretrizes definidas por agências governamentais como a AERP estavam em plena execução. Visões difundidas à exaustão pela imprensa local e, 
sob essa visão, para seus correligionários, Alberto Silva não só é tratado como o construtor da autoestima do piauiense, mas também como o responsável pelo reconhecimento nacional de sua existência, chegando ao ponto de chamá-lo de "descobridor" do Piauí para o Brasil. Essa passou a ser a formulação mais utilizada pelos adeptos desse governo a partir de então no esteio da "invenção das tradições" (HOBSBAWM; RANGER, 1997).

O caráter desbravador do político parnaibano foi realçado nas construções discursivas feitas por seus aliados, passando a assumir o status de "descobridor" do Piauí, ao propagarem essa imagem em todas as oportunidades. Alberto Silva acreditava, assim, poder tornar-se imortal para a história deste estado. Seu caráter empreendedor passou a ser realçado mesmo entre seus críticos.

Até mesmo os opositores políticos de Alberto Silva destacavam suas ações no sentido de estimular a imagem positiva do piauiense sobre si mesmo, reconhecendo suas intervenções exitosas em defesa dessa autoestima. Djalma Veloso $^{16}$, ao falar sobre essa questão, informou que o governo de Alberto Silva contribuiu bastante para elevar a imagem do Piauí em nível nacional, saindo da condição de deboche à condição de integrante respeitado do mapa nacional. Comentando a respeito do tratamento dado ao Piauí pela imprensa e à reação tomada pelo governador na época, destacou que:

O Piauí era levado no deboche nacional. As revistas de grande circulação, como a "Realidade", mostravam a nossa bandeira como sendo um couro de bode. Em razão disso, os mais exaltados fizeram fogueiras e mais fogueiras ${ }^{17} \mathrm{com}$ essas revistas em pleno tumulto das praças João Luiz Ferreira e Rio Branco, tradicionais pontos de vendas dessas publicações. Ora, a nossa história, tirando os índios que aqui viveram, deve muito aos vaqueiros, à criação do boi e, também, do bode. O Alberto Silva reverteu essa situação, botando, com muita garra, dinamismo e competência, o Piauí no mapa brasileiro de maneira decente. O seu primeiro governo foi, realmente, de pleno desenvolvimento (VELOSO apud KRUEL, 2006, p. 413).

\footnotetext{
${ }^{16}$ Nascido em Valença, em 1922. Assumiu, entre outros, o cargo de vice-governador do Piauí (19751978) e o cargo de governador do Piauí em 1978, após Dirceu Arcoverde afastar-se para concorrer ao mandato de senador. Faleceu em 2007.

17 Há registros de mobilizações realizadas em praça pública para queimar a revista. Uma dessas ocorreu na praça Pedro II e foi organizada por estudantes da Faculdade de Direito do Piauí e da Faculdade Católica de Filosofia (TAVARES, 2018).
} 
Nesse discurso, o inimigo externo, representado pelo veículo midiático, novamente é o recurso utilizado para cimentar o desejo de pertencimento ao Piauí. Pretende-se convencer o piauiense da existência desse inimigo e da necessidade de silenciá-lo com respostas à altura. Conforme essa construção, a identificação da população com sua terra seria, portanto, a única arma de combate contra tais ofensas. Nessa construção discursiva, novamente Alberto Silva é o cavaleiro que combate as injúrias com sua espada do desenvolvimento, "revertendo essa situação" e "botando [...] o Piauí no mapa brasileiro".

Esse pronunciamento em prol da autoestima piauiense muito se assemelha ao realizado pelo governador do Ceará durante a reunião da SUDENE, em novembro de 1971, em que ele contestava veementemente notícias publicadas pela imprensa do Centro-Sul sobre o empobrecimento e a "falência" do Nordeste, recebendo o apoio dos demais governadores (BRASIL, SUDENE..., 1971 apud CARVALHO, 1987, p. 147). A construção de uma imagem otimista estava em conformidade com o ideal desenvolvimentista do país, não sendo, portanto, uma iniciativa exclusiva da administração de Alberto Silva. Isso não impediu, contudo, que o perfil heroico cortejasse sua trajetória administrativa durante a primeira gestão, tornando-se o símbolo de sua vida política e o referente de sua imagem na memória piauiense. Acreditamos que esses sistemas de representação estão relacionados à atuação estratégica de Armando Madeira Basto, que antes de assumir a Assessoria de Acompanhamento e Comunicação do estado do Piauí (AGE) - responsável pela comunicação social do governo estadual, atuando no campo do jornalismo, das relações públicas, da publicidade, da propaganda e do marketing político -, havia ocupado vários cargos de prestígio na comunicação do Governo Federal, sendo um dos elos entre as duas esferas administrativas.

Quando Djalma Veloso reconhece virtudes em Alberto Silva, emite algumas das ressonâncias que ecoam na memória coletiva no presente, confirmando a ideia de que esta liderança política seria um componente decisivo na construção não só do Piauí, mas de sua gente. A opinião de Veloso também precisa ser lida na circunscrição histórica na qual foi formulada, uma vez que as memórias não são prisioneiras fixas do tempo, mas, ao contrário disso, transformam-se também mediante a configuração histórica à qual estão submetidas. Michel de Certeau 
enuncia, inclusive, que a memória é uma prática regulada pela alteração, uma rememoração pelo outro e que é tocada pelas circunstâncias, "é narração, não descrição. É uma arte do dizer" que é "tocada pelas circunstâncias, como um piano que produz sons ao toque das mãos", sendo ela, portanto, um "sentido dos outros" (CERTEAU, 2004, p. 154).

A composição desses "sons" está inter-relacionada ao lugar social da produção. Por isso, é importante entender que esse depoimento de Djalma Veloso, emitido em 2006, é a fala de um personagem que historicamente foi um forte adversário político de Silva, mas que reconhece que as tensões políticas entre ambos há muito foram atenuadas. Assim, as disputas que marcaram as trajetórias de vida dos dois também foram desbotadas com a passagem do tempo, possibilitando a emissão de alguns pareceres favoráveis do primeiro em relação às ações do segundo, divergindo das posturas combativas assumidas em décadas anteriores. Tensões antigas atenuadas, novas formulações tocam e atingem a memória, reformulando-as.

Dar visibilidade aos feitos de Silva no sentido de esse ter criado uma imagem positiva do Piauí na década de 1970 significa que Djalma Veloso reconhece o capital político conquistado pelo político parnaibano em sua trajetória pública. A força da imagem positiva desse administrador na memória coletiva e do prestígio que ele continuou gozando junto à sociedade piauiense ajudam a explicar um pouco esse parecer positivo formulado por um tradicional opositor na política estadual. Segundo a construção discursiva de Veloso, Alberto Silva fora responsável pela inserção do Piauí no mapa brasileiro por meio das ações em prol do desenvolvimento da região, escrevendo e inscrevendo seu nome definitivamente na história e perpetuando-se por meio disso. Suas circunstâncias fizeram com que ele ouvisse novos sons a respeito da imagem de Silva em sua memória, emitindo também outras composições no cenário local. Constituiu-se uma significativa cartografia identitária, tendo, na personificação de Silva, a coluna de sustentação desses "novos" limites da identidade piauiense.

De acordo com essa visão, ao mesmo tempo em que assumia a condição de cartógrafo do mapa brasileiro, o ex-governador parnaibano cartografava também a autoestima do piauiense. O engenheiro continuava em plena atuação com "garra, 
dinamismo e competência" (VELOSO apud KRUEL, 2006), construindo o Piauí e sua gente. O "recinto do elogio", mediante tal formulação, ganhava mais um adepto entre aqueles que outrora empreenderam oposição à sua imagem, ao indicar que as críticas adversárias não conseguiram se impor ao prestígio usufruído, nem tampouco conseguiram aplacar o reconhecimento que Silva obtivera na política local.

Em seus depoimentos, todavia, Djalma Veloso faz questão de afirmar que, embora fosse do grupo dos políticos que faziam oposição a Alberto Silva, sempre tivera grande admiração por ele e por suas ações quando esteve à frente de seu primeiro governo do Piauí. Fez questão, inclusive, de salientar, em um livro que conta sua trajetória de vida, que a admiração por Silva era contemporânea ao período de maior disputa entre seus grupos políticos. Esclareceu que quando inquirido por um aliado de Silva - o deputado Figueiredo de Mesquita - sobre qual seria seu posicionamento se houvesse uma disputa direta entre Alberto Silva e Petrônio Portella, em relação a um cargo de comando no Piauí, na década de 1970, revelou grande simpatia por Silva ao emitir a seguinte resposta:

Embora eu tenha uma grande admiração, um grande respeito e até mesmo uma grande gratidão pelo governador Alberto Silva, que está redimindo este Estado, que está realizando obras de grande importância para o Piauí, que está levantando a estima do nosso povo, não tenho dúvida de que, numa disputa entre os dois, eu ficarei do lado do senador Petrônio Portella Nunes. Somos da mesma terra, fomos criados praticamente juntos, portanto, eu sou ligado é ao senador Petrônio Portella Nunes. (VELOSO apud KRUEL, 2006, p. 421, grifo nosso)

Mais uma vez, o caráter heroico e empreendedor de Alberto Silva é destacado por um adversário, que mesmo afirmando fazer-lhe oposição, declara admirá-lo e ser-lhe grato por suas iniciativas em "redimir" o Piauí, em levantar "a estima" de sua população por meio das obras realizadas no surto desenvolvimentista implantado no estado em seu primeiro mandato. Entre as principais construções albertistas, na visão de Veloso, a maior fora a elevação da autoimagem que o piauiense passou a sentir por si mesmo. O próprio Alberto Silva, ao ser perguntado sobre qual a principal obra que construíra, ratificou: "[...] de um 
modo geral creio que o maior trabalho foi no sentido da autoestima, o Piauí começou a acreditar nele mesmo" (SILVA, 2008).

Mais do que revelar sobre o período ao qual o depoimento se refere, esse discurso fala do presente no qual ele está inserido. Um presente que continua a prestigiar e louvar a figura de Alberto Silva, perante o qual ele ainda assume o papel de um empreendedor admirado por significativa parcela da sociedade piauiense, principalmente pelas características de seu primeiro governo. Essa admiração é percebida não só pela expressiva votação que continuou a receber nas eleições subsequentes, nem pelos elogios feitos a ele por representantes dos diferentes setores sociais, mas principalmente pela sua influência em questões decisórias do cenário político até seu falecimento, em 2009, ambiente no qual ele gozava de muito prestígio e por onde paravam decisões vitais ao estado.

As reverências aos feitos de Alberto Silva, dessa forma, precisam ser entendidas não apenas como atribuídas ao indivíduo ex-governador, mas a uma memória construída em relação a ele e a seu primeiro governo. Os dividendos sociais e políticos gerados por essa memória podem ser maiores que qualquer permanência de oposição. O tempo, que tudo devora, parece mais ter protegido e preservado tal imagem para o presente que a corroído, ganhando o status de aliado dessa memória, passando a revigorá-la.

Isso faz lembrar as declarações de Roger Chartier, quando ele esclarece que a construção da identidade do indivíduo situa-se "no cruzamento da representação que ele dá de si mesmo e da credibilidade atribuída ou recusada pelos outros a essa representação"; sendo que a superioridade social de um projeto ou grupo define-se "pela submissão política e simbólica" (CHARTIER, 1988, p. 111-112).

\section{Considerações finais}

O projeto difundido por Alberto Silva sobre a decisiva participação de seu governo na construção da autoestima piauiense, marcando a identidade desse povo, não pode ser dissociado do projeto político-ideológico em vigência no Brasil, na década de 1970, que visava a criar - e criou - meios de representação de um país em euforia. 
Discutimos que, inseridas nessa ação, estavam as proposições elaboradas por órgãos governamentais como a AERP e a AGE - responsáveis pela elaboração e articulação de campanhas de publicidade e propaganda. Todavia, não ignoramos as contradições presentes nesse discurso e nas práticas sociais que o alicerçavam - num contexto marcado pela repressão, pela censura e pela autocensura, que ajudaram a difundir uma percepção otimista de país como mecanismo de contenção contra os protestos sociais.

Esse clima de euforia, com a defesa da ideia de prosperidade e de autoconfiança, era projetado como bálsamo para todos os males vividos no país e no estado - sobretudo os de cunho político e social, como os que tratavam o Piauí pelo único viés de estado "atrasado" e ridicularizado pela imprensa nacional. Mas, os contestadores dessas críticas pouco ou nada refletiram ou fizeram para reverter sobre as condições sociais que levaram o estado ao anedotário nacional.

Passaram apenas a adotar as críticas como o mote para difundir o papel de Silva como "construtor da identidade piauiense". As críticas recebidas passaram a funcionar apenas como o "inimigo" a ser combatido, que servia para inspirar a defesa da autoestima piauiense como inspirador do "mito fundacional" da sociedade.

Defendemos, assim, que essas ações, embora tenham repercutido sobre como a sociedade local passou a perceber sua própria imagem, não foram fruto exclusivo da originalidade do governo piauiense, uma vez que estavam integradas ao projeto político estratégico vigente no país, que adotava o discurso de otimismo como elemento de sustentação dos governos autoritários. Por isso, falamos em "usos políticos" da autoestima piauiense.

Acreditamos, contudo, que isso não atenue a força com que a administração de Alberto Silva deixou suas marcas na memória e na história piauiense, a ponto de ser recorrente a menção a seu nome quando este é o tema em apreço, inclusive entre seus principais oponentes políticos.

Preferimos não reduzir a história apenas a uma dimensão maniqueísta e dual, em que a história ocorreria como projeção previamente definida por seus governantes, pois, se as decisões do governo do Piauí não estavam desarticuladas 
do cenário histórico nacional, também não podem ser lidas apenas como mero cumprimento mecânico do projeto definido pela cúpula dos governos militares que o nomearam.

Tampouco podemos minimizar as repercussões e apropriações dos meios de representação sobre a autoestima piauiense ao controle político nacional, pois também é importante perceber como se deu a relação de forças nas representações sociais no estado, inclusive as que contribuíram para a sociedade reconhecer a existência de singularidades socioculturais e históricas a partir de uma identificação com as representações produzidas acerca de sua autoestima nesse período.

\section{Referências}

ABREU, Alzira A. de. As mudanças na imprensa brasileira: 1950-1970. In: LUSTOSA, Isabel (org.). Imprensa, história e literatura. Rio de Janeiro: Edições Casa Rui Barbosa, 2008. p. 467-480.-

ABREU, Alzira A. de; PAULA. Christiane J. de. Dicionário histórico-biográfico da propaganda no Brasil. Rio de Janeiro: Editora FGV/ABP, 2007.

ALBERTI, Verena. Ouvir contar: textos em história oral. Rio de Janeiro: Editora FGV, 2010.

AMADO, Janaina; FERREIRA, Marieta M. (orgs.). Introdução. In: Usos \& abusos da história oral. 6. ed. Rio de Janeiro: Editora FGV, 2006. p. vii-xxv.

BASTOS, Cláudio. Dicionário histórico e geográfico do Estado do Piauí. Teresina: Fundação Cultural Monsenhor Chaves, 1994.

BAUMAN, Zygmunt. Identidade: entrevista a Benedetto Vecchio. Trad.: Carlos Alberto Medeiro. Rio de Janeiro: Jorge Zahar, 2005.

BÉDARIDA, François. Tempo presente e a presença da história. In: AMADO, Janaina; FERREIRA, Marieta M. (orgs.). Usos e abusos da história oral. Rio de Janeiro: Editora da FGV, 2006. p. 219-229.

BENJAMIN, Walter. O narrador. Considerações sobre a obra de Nikolai Leskov. In: MAGIA E TÉCNICA, ARTE E POLÍTICA: obras escolhidas. 3.ed. São Paulo: Brasiliense, 1987. p. 197-221.

CARVALHO, Inaiá Maria M de. O Nordeste e o regime autoritário. São Paulo: HUCITEC: SUDENE, 1987. 
CERTEAU, Michel de. A invenção do cotidiano: 1. Artes de fazer. 10 ed. Petrópolis: Vozes, 2004.

CHARTIER, Roger. A história cultural: entre práticas e representações. Lisboa: Difusão Editorial, 1988.

COUTO, Mia. Poemas escolhidos. São Paulo: Companhia das Letras, 2006.

FERREIRA, Marieta de Moraes. História oral: velhas questões, novos desafios. In: CARDOSO, Ciro Flamarion; VAINFAS, Ronaldo (orgs.). Novos domínios da história. Rio de Janeiro: Elsevier, 2012. p. 169-186.

FICO, Carlos. Reinventando o otimismo: ditadura, propaganda e imaginário social no Brasil (1969-1977). Rio de Janeiro: FGV, 1997.

FICO, Carlos. Espionagem, polícia política, censura e propaganda: os pilares básicos da repressão. In: FERREIRA, Jorge; DELGADO, Lucilia de Almeida Neves. (orgs.). O Brasil Republicano: o tempo da ditadura: regime militar e movimentos sociais em fins do século XX: Livro 4. 2 ed. Rio de Janeiro: Civilização Brasileira, 2007, p. 167-205.

FONTINELES, Cláudia C. S. da. Recinto do elogio e da crítica: maneiras de durar de Alberto Silva na memória e na história piauiense. 2009. Tese (Doutorado em História) - Universidade Federal de Pernambuco, Recife, 2009.

GRINBERG. Lúcia. Partido político ou bode expiatório: um estudo sobre a Aliança Renovadora Nacional (Arena): 1965-1979. Rio de Janeiro: Mauad X, 2009.

HALL, Stuart. A identidade cultural na pós-modernidade. 12 ed. Trad.: Tomaz Tadeu da Silva; Guacira Lopes Louro. Rio de Janeiro: Lamparina, 2015.

HOBSBAWM, Eric; RANGER, Terence. A invenção das tradições. Rio de Janeiro: Paz e Terra, 1997.

KRUEL, Kenard. Djalma Veloso: o político e sua época. Teresina: Halley S.A., 2006.

KUSHNIR, Beatriz. Cães de guarda: jornalistas e censores, do Al-5 à Constitução de 1988. São Paulo: Boitempo, 2012.

MARTINS, Ana Luiza; LUCA, Tânia Regina de (orgs.). História da imprensa no Brasil. São Paulo: Contexto, 2008.

OS MILITARES: teoria e prática do poder. Veja, São Paulo, p. 2, 1 abr. 1970.

PESAVENTO, Sandra Jatahy. Cidades Invisíveis, Cidades Sensíveis, Cidades Imaginárias. Revista Brasileira de História, São Paulo: ANPUH, v. 27, n. 53, p. 11-23, jan./jun. 2007. Disponível em:

https://www.scielo.br/scielo.php?script=sci_arttext\&pid=S0102-

01882007000100002. Acesso em: 12 jun. 2018. 
PIAUÍ. Mensagem do Governador do Estado Alberto Tavares Silva encaminhada à Assembleia Legislativa. Teresina: [s.n.], 1 mar. 1975.

PIAUÍ. Mensagem do Governador do Estado Alberto Tavares Silva encaminhada à Assembleia Legislativa do Estado do Piauí. [Teresina: s.n.], 1 mar. 1972. p. 3.

REIS, Marcela M. F. dos. Do riso ao grito: a atuação dos jornais Gramma e Chapada do Corisco na década de 1970 em Teresina. 2013. Dissertação (Mestrado em Comunicação Social) - Universidade Federal do Piauí, Teresina, 2013.

RICCEUR, Paul. A memória, a história, o esquecimento. Campinas: Editora UNICAMP. 2007.

RODRIGUES, Nelson. O reacionário: memórias e confissões. Rio de Janeiro: Agir, 2008. E-book.

SILVA, Alberto Tavares. [Entrevista concedida a] Cláudia Cristina da Silva Fontineles. Teresina, 03 out. 2006.

SILVA, Alberto. [Entrevista concedida a] Elivaldo Barbosa. Teresina: TV Cidade Verde, Jornal do Piauí, 11 abr. 2008.

SODRÉ, Nélson Werneck. História da imprensa no Brasil. 3 ed. São Paulo: Martins Fontes, 1983.

TAVARES, Zózimo. 100 fatos da história do Piauí no Século XX. 3. ed. Teresina: Halley, 2000.

TAVARES, Zózimo. Alberto Silva: uma biografia. Teresina: Bienal Editora, 2018.

TEIXEIRA, Tomaz. Combate: a esperança de vencer: depoimento. Teresina: [s.n.], 1990.

TEIXEIRA, Tomaz. A outra face da oligarquia do Piauí. Fortaleza: Stylus Comunicação. 1981.

Universidade do Estado de Santa Catarina - UDESC

Programa de Pós-Graduação em História - PPGH

Revista Tempo e Argumento Volume 13 - Número 33 - Ano 2021 tempoeargumento@gmail.com 